\title{
SIVADÓ MÁTÉ \\ Új politikák a drogjelenség kezelésében, kitekintéssel az alkoholra
}

A legtöbb kutató egyetért abban, hogy a drogjelenség kezelésének három nagy eszközcsoportja van: a kereslet-, a kínálat- és az ártalomcsökkentés. A keresletcsökkentés a drogok iránti igény mérséklésén alapul. Ezek az eszközök kecsegtetnek némi eredménnyel, mivel tudjuk, hogy a drogpiacot az igények mozgatják. Ez a terület nagyon idő- és pénzigényes. Nem kínálnak négy évben mérhető látványos megoldásokat. Ezért az e tárgyban tett intézkedések nagyrészt ki is merülnek a látszatcselekvésben, illetve néhány mélyen elhivatott szakember emberfeletti munkájában. Az iskolákban folyó DADA-, Ellenszer és hasonló programokat lekiismeretes, jószándékú hivatásosok és civilek végzik nagy hittel, e programok hatásfokáról azonban megoszlanak a vélemények. Egyre inkább úgy tünik, hogy a leginkább veszélyeztetett kiskamasz, illetve pubertás korosztályok tagjait nem lehet elrettenteni a drogok veszélyeire hivatkozással. Erre a korcsoportra, különösen a fiúkra, éppen a veszély keresése a jellemző. A friss jogosítványos tizenéves fiú sem azért hajt gyorsan az apja kocsijával, mert nem tudja, hogy mennyi a sebességkorlát, vagy ne lenne tisztában a gyorshajtás veszélyeivel. Pontosan a dolog veszélye miatt cselekszik így. Nincs okunk azt feltételezni, hogy a drogok esetében más lenne a helyzet. Ezért nem hiszek az elrettentés erejében.

A kínálatcsökkentés a legkommerszebb eszközrendszer. A közönség imádja, a szavazók vevők rá, a rendészeti apparátus pedig igazolhatja vele önnön fontosságát. A lényege szerint az állam rendészeti-jogi - szélsőséges esetben hadi - eszközökkel lép fel a drogterjesztők és -fogyasztók ellen. A kérdéssel kevesebbet foglalkozók számára úgy tünhet, hogy ezzel valódi, látványos eredmények érhetők el. A látvánnyal nincs is baj. Az alsógatyában földön fekvő drogterjesztők hátán térdelő kommandósok vagy a nagy menynyiségü lefoglalt drog látványa erôteljes. Továbbá azt közvetíti az embereknek, hogy mostantól a piacon kevesebb lesz a drog és a -terjesztő. Ennek hamisságával azonban minden szakember tisztában van. A kieső dílerek helyére pillanatok alatt lép az újabb szereplö, a lefoglalt drogot napok alatt pótolják. A konkrét eredmény az, hogy erre a pár napra a kábítószer piaci ára emelkedik. Érdekes jelenség továbbá, hogy a nagy fogások után gyakran hallhatunk 
drogos halálesetekről. Ezeket sokáig azzal magyarázták a szakértők, hogy a korábban megszokotthoz képest nagyobb tisztaságú anyag kerül a piacra, amelyből a fogyasztó a szokásos mennyiséget adagolja, majd túladagolásban meghal. Bármennyire logikus is, nem ez az igazság. A drogfogyasztásra tartósan berendezkedett személyek szervezetében magas tolerancia alakul ki a használt anyag iránt. Így lehetséges az, hogy aki több éve fogyaszt heroint, annak a nemfogyasztók számára halálos dózis sem okoz súlyosabb egészségkárosodást. A lefoglalások miatt kialakuló ellátási nehézségek idején ez a tolerancia csökken. Amikor újra hozzájut a függő az anyaghoz, a korábban megszokott-tolerált mennyiséget injektálja, majd meghal. A szakemberek összességében arra a megállapításra jutottak, hogy bár nagyon fontos eszköz a drogkereskedelem elleni rendészeti fellépés vagy akár a fenyegetés, de hatástalan.

Az ártalomcsökkentés a harmadik és legkésőbb felismert út. Egy olyan alapvetéssel kezdődik, amely a legtöbb, illegális drogot nem fogyasztó ember számára elfogadhatatlan. Azzal, hogy tudomásul vesszük a következőket:

- a drogmentes társadalom elérhetetlen eszménykép;

- a legális és illegális drogok között hatásmechanizmusukban, veszélyességükben nincs különbség;

- vannak olyan drogfogyasztók, akik nem akarnak, illetve nem tudnak lemondani a fogyasztásról;

- a kényszerítő kezelések hatástalanok a drogfogyasztás esetén.

Meggyőződésem szerint a drogpolitika súlypontját a kereslet- és az ártalomcsökkentésre kell helyezni, ellentétben a mai helyzettel, amikor a kínálatcsökkentést preferáljuk. Lássunk két példát, amelyek alátámasztják a kínálatcsökkentésre fordított erőfeszítések eredménytelenségét!

\section{Amerikai Egyesült Államok}

Amióta az Egyesült Államokban drogpolitika létezik, a büntető jellegü intézkedések és az utólagos beavatkozás preferálása volt jellemző. Ma is több százezer ember ül büntetés-végrehajtási intézetekben fogyasztási mennyiségü kábítószer birtoklásáért. Ennek ellenére Amerika területén bárhol könnyen beszerezhető gyakorlatilag bármilyen illegális kábítószer. Az utóbbi években ez a tendencia megváltozott, sorra születnek a törvények a marihuána dekriminalizása vagy éppen legalizációja vonatkozásában. 
Az Egyesült Államokban a börtönlakók több mint fele droggal való visszaélés miatt tölti a szabadságvesztés-büntetését (táblázat). ${ }^{1}$

Büncselekmények megoszlása az Egyesült Államokban fogva tartottak körében²

\begin{tabular}{|l|l|r|r|}
\hline \multirow{2}{*}{ Címke } & \multirow{2}{*}{ Bűncselekmény } & \multicolumn{2}{|c|}{ Fogvatartottak } \\
\cline { 3 - 4 } & & száma & \multicolumn{1}{c|}{$\%$} \\
\hline a) & Banki és biztosítási bủncselekmények, hamisítás, sikkasztás & 737 & 0,4 \\
b) & Betörés, lopás, tulajdont sértő bủncselekmények & 7994 & 3,9 \\
c) & Bủnszövetkezetben részvétel & 475 & 0,2 \\
d) & (bírósági) korrekciós ítéletek & 663 & 0,3 \\
e) & Kábítószer-bủncselekmények & 100867 & 49,8 \\
f) & Zsarolás, csalás, vesztegetés & 11210 & 5,5 \\
g) & Emberölés, súlyos testi sértés, emberrablás & & \\
& és más személy elleni eröszakos büncselekmények & 5683 & 2,8 \\
h) & Migrációs bủncselekmények & 21057 & 10,4 \\
i) & Egyéb büncselekmények & 1598 & 0,8 \\
j) & Állam elleni bủncselekmények & 77 & 0,0 \\
k) & Rablás & 7708 & 3,8 \\
l) & Szexuális bủncselekmények & 12594 & 6,2 \\
m) & Fegyverrel, robbanóanyaggal visszaélés, gyújtogatás & 31791 & 15,7 \\
\hline
\end{tabular}

Az Egyesült Államokban a szövetségi törvények értelmében a cannabis használata, értékesítése és birtoklása illegális, de a szövetségi kormány bejelentette, hogy az egyes államok dekriminalizálhatják a cannabis rekreációs használatát, ha megteremtik ennek pontos szabályozási rendszerét. A szövetségi törvény indoklása szerint a cannabis használatakor nagy a hozzászokás veszélye, és nincs orvosi indoka a használatnak. ${ }^{3}$

2002-ben Nevadában népszavazást írtak ki abban a kérdésben, hogy törvényes legyen-e akár három uncia ( 85 gramm) marihuána birtoklása, huszonegy évesnél idősebbek számára. A támogatók aránya harminckilenc százalék volt, így a kezdeményezés elbukott.

2006-ban egy hasonló kezdeményezés történt szintén Nevadában,ez már legalizálta és szabályozta volna a marihuánatermesztést és -birtoklást legfel-

1 http://444.hu/2014/07/06/ki-nem-talalna-hogy-a-legtobb-amerikai-elitelt-miert-kerult-bortonbe/

2 Rollie Williams: It's No Longer Hard To Guess Why People Are In The Federal Prison.

http://www.upworthy.com/its-no-longer-hard-to-guess-why-people-are-in-federal-prison

3 Federal Food, Drug, and Cosmestic Act. Public Law, 75-717, 52 STAT 1040, which prohibited the movement in interstate commerce of adultered and misbranded food, drugs, devices, and comestics. 06/25/1938. 
jebb egy unciáig (28 gramm) huszonegy évesnél idősebbek számára. Ezen a szavazáson az igenek aránya negyvennégy százalék volt, így a szabályozást nem vezették be.

2006-ban Dél-Dakotában szavaztak a kérdésben. A polgároknak abban kellett dönteniük, lehetővé tegyék-e az orvosi marihuána használatát, egészségileg indokolt esetben, orvos által ellenörzött körülmények között. A támogatók negyvennyolc százaléknyian voltak.

2009 júliusában Gil Kerlikowske, a Nemzeti Drogellenőrzési Hivatal igazgatója egyértelmủvé tette a szövetségi kormány álláspontját, és kijelentette, hogy „, a marihuána veszélyes és nincs gyógyászati elönye [...] a legalizálás nem szerepel az elnök szótárában, és az enyémben sem". ${ }^{4}$

2012. november 6-án népszavazást rendeztek Colorado és Washington államban, ennek eredményeképp legalizálták a rekreációs cannabishasználatot.

Az egyes állami törvények azonban nem mindig felelnek meg a szövetségi szabványnak. Számos állam dekriminalizálta a marihuánát különböző mértékben, más államokban mentességet élveznek a kifejezetten orvosi célú cannabishasználók.

Az Egyesült Államok kontra Oakland Cannabis Buyers'Cooperative- és a Gonzales kontra Raich-ügyben az Egyesült Államok legfelsőbb bírósága kimondta, hogy a szövetségi kormány nem adja fel azt a jogát, hogy szabályozza és kriminalizálja a cannabist. Továbbá, hogy a szövetségi törvény még mindig elsőbbséget élvez az egyes államok szabályozásaival szemben.

\section{Szabályozás az egyes államokban}

Mexikó

2006-ban Felipe Calderón egykori mexikói elnök összefogott az Egyesült Államokkal a drogkartellek ellen. A megállapodás alapja az a tény volt, hogy az Egyesült Államokban forgalomba kerülő drogok, ezen belül kiemelten a kokain, a heroin, a metamfetamin és a marihuána jelentős része Mexikón keresztül érkezik az országba. A kínálatcsökkentési gondolkodásból egyenesen következett: zúzzuk szét a mexikói drogkartelleket, akkor megszűnik a drogok Amerikába áramlása, így kvázi a drogprobléma is. ${ }^{5}$

\footnotetext{
4 Gil Kerlikowske: Obama's New Drug Czar.

http://content.time.com/time/politics/article/0,8599,1879306,00.html

5 http://en.wikipedia.org/wiki/Legality_of_cannabis_by_U.S._state
} 
Véleményem szerint az alapelgondolás is sántít. Ha ugyanis ez a vállalkozás sikerrel jár, az Egyesült Államokban mutatkozó drog iránti jelentős igényt nyilvánvalóan más forrásokból elégítették volna ki. Kezdetben a helyi rendészeti és igazságügyi, valamint katonai erőkre támaszkodtak, megerősítve ezeket egyesült államokbeli pénzzel, eszközökkel. Ezekről a szervezetekről kiderült, hogy velejéig korruptak, sőt a korábbi kormányzatokkal karöltve jelentős mértékben felelősek a kartellek kialakulásáért, illetve megerősödéséért. 1995 és 2011 között a mexikói statisztikák szerint százezer ember halt erőszakos halált Mexikóban. A becslések szerint ennek hatvan százaléka köthető valamilyen módon a kábítószerekhez. 2012-ben új elnök került hatalomra az országban, Enrique Peña Nieto. Ígéretet tett, hogy megfékezi az erőszakot, csökkenti az emberrablások és az emberölések számát; ez regnálása első évében sikerült is neki. Új jelenség volt megfigyelhető az országban, önvédelmi mozgalmak, polgárőrségek kezdték el civil kezdeményezésre a harcot a kartellek ellen. Ezeket a kormányzat támogatásban részesíti. A nagyrészt helyi gazdákból álló önvédelmi csoportok felvették a küzdelmet a kartellek ellen olyan városokban, ahol ez a kormányerőknek sem sikerült. E mozgalmak némelyike az utóbbi időben elindult az új kartellé válás útján. A legfrissebb hír pedig az, hogy felmerült a marihuána dekriminalizációja. Az elnök egyelőre a „kapudrog-elmélet”-re hivatkozással elutasította a kezdeményezést. ${ }^{6}$

\section{Chile}

Chilében a cannabis személyes célú használatra való termesztése, megszerzése eddig sem volt tilos, csak a mennyiség nem volt tisztázva, illetve a kábítószerek kategorizálásakor egy kalap alá került a heroinnal és a kokainnal. Chilében a hatóságok statisztikái szerint a használt drog kilencven százaléka cannabis, amelyet rekreációs drogozás keretében fogyasztanak. A 2014. július 22-én benyújtott törvényjavaslat szerint szigorúan magánhasználatra legális lenne három virágzásban lévő cannabisnövény tartása. A nyilvános helyen való fogyasztást, illetve a kereskedelmet továbbra is szigorúan büntetni rendelné a törvényjavaslat. ${ }^{7}$

6 http://www.cfr.org/mexico/mexicos-drug-war/p13689

$7 \mathrm{http} / /$ www.druglawreform.info/en/country-information/chile/item/202-chile?pop=1\&tmpl=component\&print $=1$ 
Németország

Németországban egy kölni bíróság precedensértékü ítéletet hozott: engedélyezte betegeknek, hogy saját részre cannabist termesszenek, fájdalomcsillapítás céljából. Olyan betegekről van szó, akiknek nagy fájdalmaik vannak, és egyéb csillapítási módok egyáltalán nem vagy kevésbé hatásosak, mint a marihuána. A bíróság egyben kötelezte az illetékes hivatalt, hogy bocsássa ki a szükséges engedélyeket. Németországról tudni kell, hogy hárommillióan fogyasztanak rendszeresen marihuánát, tizennégymillióan pedig már kipróbálták. ${ }^{8}$

\section{Jamaica}

Jamaicáról a legtöbb embernek a reggae és a füfogyasztás jut eszébe, ennek ellenére szigorú szankciókkal fenyegetik a fogyasztókat is. Egy 2001-es jelentés a dekriminalizáció szükségességére hívta fel a figyelmet, de az Egyesült Államok nyomására megmaradt a korábbi szabályozás. Az Egyesült Államok több államában végbemenő radikális változások azonban csökkentették ezt a nyomást. Így itt is a parlament elött van egy törvényjavaslat, amely dekriminalizálná a személyes célt szolgáló marihuánafogyasztást. ${ }^{9}$

\section{Magyarország: a dizájnerdrogok}

Az uniós országok határellenőrzésének megszünése felgyorsította a drogokmegjelenését hazánkban. Így volt ez a dizájnerdrogokkal is. A nemzetközi kábítószer-kereskedelem szereplői új stratégiát alakítottak ki. E szerint az országok kábítószerlistákra alapozott szabályozását megkerülve folyamatosan új szereket dobnak a piacra, amelyek ellen a hatóságok a tilalom hiányában nem léphetnek fel. E szerek jelentős részét Kínában állítják elő, hatalmas vegyész szakértői szaktudást és tőkét befektetve. Az ismert anyagokat minimálisan alakítják át, csupán egy-két alkotóelemet, alkaloidát módosítva. A kábítószerlistákra hagyományosan nehezen, általában több hónap után kerültek fel az új szerek. Ennek az lett a következménye, hogy a drogpiacon jelentős számú új szer volt jelen, amelyek ellen a hatóság nem léphetett fel. Ha mégis megtette, kénytelen volt visszaszolgáltatni az elosztóknak, kereskedőknek.

8 Sárosi Péter: Három ország a fülegalizáció útján.Drogriporter.blog.hu, 2014.augusztus 3. http://drogriporter.blog.hu/2014/08/03/harom_orszag_a_fulegalizacio_utjan

9 http://www.jamaicaobserver.com/news/Golding-tables-ganja-Bill-in-Senate_17045400 
Előfordult, hogy egy szállítmányt előbb a rendőrség, majd a vámhatóság is lefoglalt, majd visszaszolgáltatta a lefoglalást elszenvedőnek. Az eljárások szakértői költségei milliós nagyságrendre rúgtak. A terjesztő pedig beszkennelte a lefoglalást megszüntető határozatokat, ezzel is bizonyítva vásárlóinak, hogy nem törvénybe ütköző a kínált szer fogyasztása. A helyzet tarthatatlan volt, a törvényhozó beavatkozása halaszthatatlanná vált.

Előbb az egészségügyi törvényben jelent meg az „új pszichoaktív anyag” fogalma, majd ehhez büntetőjogi tilalmazást társítottak, hasonlóan a kábítószerrel visszaélés tényállásához. Erre a listára a korábbihoz képest sokkal gyorsabban kerülnek fel az anyagok, sőt időnként „képletgyökök” is, amelyeket aztán ha változtatgatnak is, a végeredmény tilalmazott marad. A macskaegér harc folytatódik az előállítók és a jogalkotó között. Továbbra is egyszerre több legális szer van a piacon, a fogyasztók igyekeznek ezekhez hozzájutni. Ezek a szerek ugyanis mindig jelentősen olcsóbbak, mint tilalmazott társaik. Ez is jól bizonyítja azt a tételt, miszerint az illegális kábítószerek árának nyolcvan százalékát teszi ki a lebukás kockázata. Az új szerek azonban új veszélyt is hordoznak magukban. Míg a bejáratott forrásból származó szert a függő vagy alkalmi fogyasztó megtanulta használni, adagolni, mellékhatásait csökkenteni, addig az új anyagokról ilyen tudásuk nincs. A drogambulanciákon máris egyre több a túladagolásszerü eset. A halálozási mutatók egyelőre nem romlottak. A dizájnerdrogokkal kapcsolatos eddigi tapasztalatok utalnak továbbá arra is, hogy a korábban ismert szereknél nagyobb mértékben és gyorsabban károsítják a fogyasztó szervezetét. Kiemelendő a szerek közül az Oroszországból származó krokodil, amely nagyon gyors szövetkárosodást, -elhalást okoz.

Összefoglalásként elmondható, hogy a kínálatcsökkentésre fordított erőfeszítések egyik országban sem hozták meg a várt eredményt. Ahogyan Mexikó példája mutatja, akár soha nem látott károkhoz vezethet, polgárháborúközeli helyzetet is okozhat. A nyugat-európai példák jól mutatják, hogy a hosszú távú keresletcsökkentő programok és az ártalomcsökkentés valódi, számokban, emberéletekben mérhető eredményt hoznak. Nem véletlenül vet fel óriási társadalmi vitákat bármilyen kábítószer liberalizációja. Az biztos, hogy a jelenlegi helyzet nem tartható. Kijelenthető ez még akkor is, ha tudjuk, hogy a hazai drogfogyasztás nem közelíti meg sem a keleti, sem a nyugati szomszédjainknál tapasztalható mértéket. Ezt a kedvező helyzetet veszélyeztetik az ártalomcsökkentő programokat érő támadások. Újra fellángolt a vita a tücsereprogramok, illetve a metadonprogram létjogosultságát illetően. A világgazdaságban 2008 óta tapasztalt változás és az ennek következtében 
szükülő források veszélybe sodorták ezek müködését. A nemzetközi példák azonban óva intenek bennünket attól, hogy felszámoljuk a tủcsereprogramot. Szófiában és Bukarestben a HIV-fertőzöttek számának jelentős növekedéséhez vezetett a tücserére fordított összegek csökkentése.

\section{Az alkohol}

„A szigorúbb, vagy enyhébb állami fellépést nyilvánvalóan koronként és kultúránként eltérö megfontolások alakitják. Az alkohollal, nikotinnal, kávéval az európai kultúra »megtanult« együtt élni, minthogy használatuk évszázados múltra tekint vissza. Kezelésük márcsak azért sem vonható a kábitószerekkel egy tekintet alá, mert az ezen anyagokról rendelkezésre álló ismereteink alapján - mind az akut, mind a késöi hatás tekintetében - használatuk következményei azoktól jelentösen eltérnek. A dohányzás és a koffein bódulatot, módosult tudatállapotot egyáltalán nem hoz létre, vagyis az egyén szellemi, cselekvési szabadságára semmilyen hatással nincs. Az alkoholfogyasztás kockázatai pedig a függöség kialakulásához szükséges mennyiség és időtartam jelentösen eltérö volta miatt messze elmaradnak a kábitószerek okozta veszélyektöl, s a fogyasztás azonnali következményei is kevesebb kockázattaljárnak." megtanulhattuk, a nyugati kultúra az alkohollal, nikotinnal nem együtt élni, hanem sokkal inkább együtt halni tanult meg. ${ }^{11}$ A pszichioaktív szerek közül az alkohol tipikusan olyan, amitől nem félünk, ellenben belehalunk, ellentétben az illegális szerekkel, amelyeket sokkal nagyobb félelem övez, mint az indokolt lenne. Elmondható, hogy az alkohol és az illegális drogok között a valódi különbséget a jogi szabályozásban fedezhetjük fel, nem pedig hatásmechanizmusukban. A témában végzett kutatások kivétel nélkül igazolják, hogy a szerek veszélyessége teljes mértékben független a jogi besorolásuktól. Mindenesetre az alkoholt minden vizsgálat az öt legveszélyesebb szer közé sorolja.

David Nutt angol kutató kimutatta, hogy az alkohol és a dohány is károsabb, mint az LSD, az ecstasy és a cannabis. Ebben a rangsorban az alkohol az ötödik a heroin, a kokain, a barbiturátok és a metadon mögött, és a dohány a kilencedik, megelőzve a cannabist, az LSD-t és az ecstasyt. ${ }^{12}$

\footnotetext{
10 244/B/2004. AB határozat, 60. o.

11 Topolánszky Ákos előadása a Civil Kábítószerügyi Koordinációs Testületetről. Kossuth Klub, 2014. május 15.

12 David J. Nutt - Leslie A. King - Lawrence D. Phillips: Drug harms in the UK: a multicriteria decision analysis. The Lancet, vol. 376, 2010, pp. 1558-1565.
} 
A pszihoaktív szerek közül a dohányzásnak és az alkoholnak tulajdonítható a legtöbb haláleset. A Word Health Report 2002-es jelentése szerint a halálesetek 8,9 százaléka a pszichoaktív szerek fogyasztásának tulajdonítható. Ebből 4,1 a dohányzás, 4 az alkohol, és 0,8 százalék az illegális drogok következménye. Ez 2000-es adat. Ugyanez Észak-Amerika és Európa férfi lakosságára lebontva: dohányzás 17,1, alkohol 14, illegálisdrog-fogyasztás 2,3 százalék. ${ }^{13}$ A WHO 2003-as jelentése szerint Magyarországon a betegséget okozó faktorok közül a férfiak esetén a dohányzás 25,5 , az alkohol 22,8 százalékkal részesedik. ${ }^{14}$

Úgy tűnik, mintha az előbbi adatokról mit sem tudnának a drogpolitika alakítói, pedig ez nyilván nincs így. Drogügyi szakpolitukusként David Nutt szolgált munkáspárti és konzervatív kormányt egyaránt. Ahogy rávilágított az alkohol és a nikotin okozta veszélyekre, azonnal elbocsátották.

Mindezek alapján belátható, hogy új megközelítésre van szükség az anyagfüggőségek kezelése területén. Az Egyesült Államok és Nyugat-Európa jó példával jár elöl a dohányzás visszaszorításában. Amerikában az alsó középosztálynál feljebb lévő társadalmi rétegek képviselői felhagytak a dohányzással. A skandináv országokban jelentős eredményeket értek el az alkoholizmus kezelésének területén. Jó néhány európai ország pedig valódi, számokkal kifejezhető eredményeket ért el a droggal összefüggő társadalmi gondok terén. Valószínüleg a céljainkat kell legelőször átgondolnunk. Jól látható, hogy egy globalizált világban, ahol a határok nyitottak és a súlyos társadalmi, szociális nehézségek száma határtalan, tévképzet a drogmentes társadalom. Ahogyan az erőszakos, kényszeren alapuló leszoktatás is utópia a legtöbb függő esetében.

A megoldást valahol a hosszú távú, valóban megvalósított startégiákban látom. Az, hogy négy- vagy nyolcévente a következő kormányzat visszacsinálja azt, amit az elődeik megtettek, és ez ismétlődik ciklusról ciklusra, nyilvánvalóan nem vezet sehová.

A drogprobléma visszaszorításában jó példának tekintem a frankfurti módszert, amelyben a nyomásgyakorlás és a szociális, egészségügyi segítségnyújtás megfelelő elegye jött létre.

Új koncepciókat fejlesztettek ki, például a kárcsökkentést, ártalomcsökkentést, az úgynevezett túlélési segítséget, valamint a drogot helyettesítö anyagok rendelkezésre bocsátását. Ilyen volt például a tűcsere, a nappali me-

\footnotetext{
13 World Health Report 2002.WHO, 2002.

http://whqlibdoc.who.int/publications/2002/9241562072.pdf

14 The World Health Report 2003. http://www.who.int/whr/2003/en/whr03_en.pdf?ua=1
} 
legedő, az élelmiszer- és ruhaadományok, az orvos, a védett foglalkoztatási program, a hajléktalanszálló, a fenntartó metadonkezelés és a drogfogyasztók szobáinak létrehozása.

A rendőrség időközben megváltoztatta az ügyhöz való hozzáállását, sokkal rugalmasabbnak bizonyult, és speciális képzésre iskolázzák be azokat a rendőröket, akik ezekkel az emberekkel foglalkoznak.

A rendőrség együttmüködő, és támogatja a szociális szférát. A „hétfői megbeszéléssorozathoz" csatlakozik a „pénteki megbeszéléssorozat”, amelyen részt vesznek a rendőrkapitányságok vezetői és a szociális és segítő szolgálati helyek vezetői. ${ }^{15}$

A frankfurti módszer kezdetekor a Frankfurt frekventált helyén található parkban több ezer intravénás drogfüggő a nap 24 órájában állandó „bemutatót” tartott. A módszer nyomán a heroinfogyasztók körében a HIV-pozitívak aránya ötvenről huszonöt százalékra csökkent, a kábítószerrel való visszaélések, a rablások, a gépkocsifeltörések, a lakásbetörések száma jelentősen csökkent.

\footnotetext{
15 Birgit Wichelmann-Werth, szociológus, igazgató, a Drog- és Kábítószer Szakmai Szövetség alelnökének előadása $A$ segitő szféra és a rendészet együttmüködése az ártalomcsökkentö drogpolitika megvalósításában. Miért kell, hogy így legyen? címü, 2006. november 22-én, a Rendőrtiszti Főiskolán tartott képzésen.
} 